\title{
Correction: Role of growth arrest-specific gene 6-mer axis in multiple myeloma
}

J. S. Waizenegger $\cdot$ I. Ben-Batalla $\cdot$ N. Weinhold $\cdot$ T. Meissner $\cdot$ M. Wroblewski $\cdot$ M. Janning $\cdot$ K. Riecken $\cdot$ M. Binder $\cdot$ D. Atanackovic $\cdot$ H. Taipaleenmaeki $\cdot$ D. Schewe $\cdot$ S. Sawall $\cdot$ V. Gensch $\cdot$ M. Cubas-Cordova $\cdot$ A. Seckinger $\cdot$

W. Fiedler · E. Hesse - N. Kröger · B. Fehse - D. Hose · B. Klein · M. S. Raab · K. Pantel · C. Bokemeyer · S. Loges

Published online: 3 March 2020

(c) Springer Nature Limited 2020

\section{Correction to: Leukemia 29}

https://doi.org/10.1038/leu.2014.236

Since publication of the original article, the authors have noticed an error in the legend of Fig. 7. The legend reads: "(b, c) Administration of warfarin at $1 \mathrm{mg} / \mathrm{ml}$ drinking water reduces overall survival", but should read: “(b, c) Administration of warfarin at $1 \mathrm{mg} / \mathrm{ml}$ drinking water increases overall survival". The figure is described correctly elsewhere in the article, and the error does not affect the overall findings of the paper. The authors apologise for any inconvenience caused. 